\title{
Community analysis of bacteria colonizing intestinal tissue of neonates with necrotizing enterocolitis
}

Birgitte Smith ${ }^{1}$, Susan Bodé ${ }^{3}$, Bodil L Petersen ${ }^{4}$, Tim K Jensen², Christian Pipper ${ }^{5}$, Julie Kloppenborg ${ }^{4}$, Mette Boyé2, Karen A Krogfelt ${ }^{1}$ and Lars Mølbak $2^{*}$

\begin{abstract}
Background: Necrotizing enterocolitis (NEC) is the most common gastrointestinal emergency in newborn neonates. Bacteria are believed to be important in the pathogenesis of NEC but bacterial characterization has only been done on human faecal samples and experimental animal studies. The aim of this study was to investigate the microbial composition and the relative number of bacteria in inflamed intestinal tissue surgically removed from neonates diagnosed with NEC $(n=24)$. The bacterial populations in the specimens were characterized by laser capture microdissection and subsequent sequencing combined with fluorescent in situ hybridization (FISH), using bacterial rRNA-targeting oligonucleotide probes.

Results: Bacteria were detected in 22 of the 24 specimens, $71 \%$ had moderate to high densities of bacteria. The phyla detected by $16 \mathrm{~S}$ rRNA gene sequencing were: Proteobacteria (49.0\%), Firmicutes (30.4\%), Actinobacteria (17.1\%) and Bacteroidetes (3.6\%). A major detected class of the phylum Proteobacteria belonged to $\delta$-proteobacteria. Surprisingly, Clostridium species were only detected in 4 of the specimens by FISH, but two of these specimens exhibited histological pneumatosis intestinalis and both specimens had a moderate to a high density of C. butyricum and C. parputrificum detected by using species specific FISH probes. A $16 S$ rRNA gene sequence tag similar to Ralstonia species was detected in most of the neonatal tissues and members of this genus have been reported to be opportunistic pathogens but their role in NEC has still to be clarified.

Conclusion: In this study, in situ identification and community analysis of bacteria found in tissue specimens from neonates with NEC, were analysed for the first time. Although a large variability of bacteria was found in most of the analyzed specimens, no single or combination of known potential pathogenic bacteria species was dominating the samples suggestive NEC as non-infectious syndrome. However there was a significant correlation between the presence of C. butyricum \&C. parputrificum and histological pneumatosis intestinalis. Finally this study emphasizes the possibility to examine the microbial composition directly on excised human tissues to avoid biases from faecal samples or culturing.
\end{abstract}

Keywords: FISH laser capture microdissection, microbiota, necrotizing enterocolitis, pneumatosis intestinalis, Ralstornia

\footnotetext{
* Correspondence: larmo@vet.dtu.dk

${ }^{2}$ National Veterinary Institut- DTU, Bülowsvej 27, 1790 Copenhagen V,

Denmark

Full list of author information is available at the end of the article
} 


\section{Background}

Necrotizing enterocolitis (NEC) is an acute inflammatory disease that affect the intestinal tract of neonates [1]. It remains one of the most common gastrointestinal emergencies in newborn neonates [2]. Onset of NEC occurs within the first three months of life and neonates who are of low birth weight and under 28 week gestation are the most susceptible [3]. The ileum and the proximal colon are the frequently affected although any segments of the gastrointestinal tract can be involved [4]. The course of NEC is multifactorial and the most important elements is prematurity, enteral feeding, bacterial colonization and an inappropriate pro-inflammatory response [5]. It is believed that immaturities of these functions due to age predispose the premature infant to intestinal injury and inappropriate responses to injury.

The bacterial role in NEC still needs to be clarified. Suggestions such as an imbalance of the gastrointestinal microbiota, overgrowth of potential pathogenic bacteria, and ischemia causing mucosal lesions that gives the bacteria systemic access have been followed but so far no specific pathogens have been identified. Correlation of NEC with bacteria has been suggested by analysing faecal samples, however, this analysis of faecal samples is often far from the affected site and may not be representative [5-11]. The use of formalin-fixed paraffinembedded tissue samples give an opportunity to investigate a unique stock of archival disease-specific material. The method is challenged to access the limited and fragmented bacterial DNA present in the tissue. To characterize the bacterial population in the formalin-fixed NEC tissue laser-capture-micro-dissection (LCM) combined with fluorescence in situ hybridization (FISH), using a bacteria ribosomal RNA (rRNA)-targeting oligonucleotide probe, was used [12]. The bacterial $16 \mathrm{~S}$ rRNA gene was PCR amplified and sequenced by pyrosequencing. The bacterial distribution was verified and visualized within the lumen and mucus of the intestinal tissues with fluorescent in situ hybridization (FISH) with group and species specific probes targeting individual microbial cells (Table 1). The aim of this study was to investigate the microbial composition and the relative number of bacteria in affected intestinal tissue samples surgically removed from neonates diagnosed with NEC and to relate this with the patient data such as antibiotic treatment.

\section{Result}

Twenty-four neonates with different gestational age were enrolled in this study because they all had intestinal tissues surgically removed. Sections from the small intestine were removed in 15 neonates, from both the small intestine and the large intestine for 6 neonates, and only from the large intestine in 3 neonates. Eight of the 24 neonates died but there was no correlation between NEC-score and death. All data have been described in Table 2, but in summary three neonates were full-term; two of these had heart disease and one foeto-maternal bleeding. Three neonates were small for gestation. Nine neonates had pneumatosis intestinalis and 11 neonates had free air in the stomach as observed by $\mathrm{x}$-ray. For 21 of the neonates information regarding enteral feeding was available. Mothers' breast milk or bank milk was introduced between day 1 and day 5 , and supported with either $5 \%$ or $10 \%$ glucose. If the neonate was not able to reach the level of enteral feeding after day 5 , support by paraenteral nutrition was initiated; median 8 day SD $8.9(\mathrm{n}=13)$. All neonates were treated with antibiotics for different time spans before the

Table 1 Target for probes and sequences of rRNA-targeting oligonucleotide probes and 16S rRNA gene targeting primers used in this study

\begin{tabular}{|c|c|c|c|c|}
\hline Targets for probes & Oligonucleotide Probes & Sequence & Fluorophor & Reference \\
\hline Bacteria & S-D-bact-0338-a-A-18 & 5' GCT GCC TCC CGT AGG AGT 3' & Fluorescein & {$[37]$} \\
\hline \multirow[t]{2}{*}{ Enterobateria } & GAM42a & 5' GCC TTC CCA C(AT)TCGT TT 3' & Fluorescein & {$[38]$} \\
\hline & S-S-C.perfring-185-a-A-18 & 5'TGG TTG AAT GAT GAT GCC 3' & Cy3 & {$[21]$} \\
\hline \multirow[t]{3}{*}{ Clostridium spp. ${ }^{1}$} & S-S-C.paraputri-181 & 5' CAT GCG AAC GTA CAA TCT 3' & Суз & This study \\
\hline & S-S-C. butyricum-663 & 5'AGG AAT TCT CCT TTC CTC 3' & Сy3 & This study \\
\hline & S-S-C.diff-193-a-A-18 & 5'TGT ACT GGC TCA CCT TTG 3' & Суз & {$[21]$} \\
\hline Actinobacteria & pB-00182 & 5'TA TAG TTA CCA CCG CCG T 3' & Cy3 & {$[39]$} \\
\hline Lactobacillus \& Enterococcus & Lab158 & 5'GGTAT TAJ CAY CTG TITCCA3' & Cy3 & {$[40]$} \\
\hline \multirow[t]{2}{*}{ Bifidobateria } & pB-00037 & 5'CC AGT GGC TAT CCC TGT GTG AAG G3' & Сy3 & {$[41]$} \\
\hline & PCR Primers & & & \\
\hline Bacteria & Bact64f & 5'-CY TAA YRC ATG CAA GTC G-3' & & {$[42]$} \\
\hline Bacteria & Bact109r1 & $5^{\prime}-Y Y$ CAC GYG TTA CKC ACC CGT-3' & & {$[42]$} \\
\hline Bacteria & PyroBact64f & 5'-CAT GCA AGT CG-3' & Biotin C-6 & This study \\
\hline
\end{tabular}

${ }^{1}$ The Clostridium probe is a mixture of four clostridium species: C. perfringens, C. difficile, C. butyricum and C. parputrificum 


\begin{tabular}{|c|c|}
\hline Characteristics & \\
\hline \multicolumn{2}{|l|}{ Mother } \\
\hline Antiboitics during labor, $\mathrm{n}(\%)$ & $3(13)$ \\
\hline Betamethasone, n (\%) & $14(58)$ \\
\hline \multicolumn{2}{|l|}{ Neonate } \\
\hline Mode of delivery (caesarean section), n (\%) & $14(58)$ \\
\hline $\operatorname{Sex}(m), n(\%)$ & $13(54)$ \\
\hline Number of twins, n (\%) & 7(29) \\
\hline $\begin{array}{l}\text { Gestational age (weeks), median ( } 95 \% \\
\text { confidensceinterval) }\end{array}$ & $29(25-40)$ \\
\hline $\begin{array}{l}\text { Gastational weight (g) median (95\% } \\
\text { confidensceinterval) }\end{array}$ & $\begin{array}{l}1030(600,- \\
3660)\end{array}$ \\
\hline Small for gastational age $\mathrm{n}(\%)$ & $3(13)$ \\
\hline \multicolumn{2}{|l|}{ APGAR } \\
\hline $1 \min ($ median) $n=19$ & 8 \\
\hline $5 \min$ (median) $n=20$ & 10 \\
\hline Arterial cord $\mathrm{pH}$ & 7.18 \\
\hline RDS treated with surfactant, $\mathrm{n}(\%)$ & $8(33)$ \\
\hline CPAP (median, SD) $n=20$ & $4.5(9.8)$ \\
\hline Ventilatior days (median, SD) $n=18$ & $4(12.6)$ \\
\hline Ischemems event ${ }^{1}, \mathrm{n}(\%)$ & $11(46)$ \\
\hline \multicolumn{2}{|l|}{ Ex-ray } \\
\hline pneumatosis entestinalis & 9 \\
\hline free air in the stomach & 11 \\
\hline Operation day (median, range) & $10.5(3,52)$ \\
\hline \multicolumn{2}{|l|}{ Removed tissue } \\
\hline small intestinal & 15 \\
\hline small intestinal and large intestine & 6 \\
\hline Large intestine & 3 \\
\hline
\end{tabular}

'Ischemic event: defined as one or more of this condition; perinatal asphyxia, polycythaemia, cyanotic congenital heard disease, patent ductus arteriosus, medication that suppress mesenteric blood flow, maternal preeclampsia

surgery (Table 3 ). The standard treatment for children $<7$ days was i.v. injection of ampicillin, gentamicin and metronidazole; standard treatment for children $>7$ days was i.v. injection of cefuroxim, gentamicin and metronidazole. The antibiotic treatment will influence the general bacterial colonization but to the best of our knowledge there is no study about how it influences the bacterial composition and load of the NEC affected intestinal tissues in humans.

\section{Detection of bacteria in tissue samples by fluorescent in situ hybridization (FISH)}

Bacteria were detected in 22 of the 24 examined specimens, and of these $71 \%$ had a moderate to a high density of bacteria (Table 3). In $17(70 \%)$ of the 24 specimens Enterobacterieceae were detected by a group specific FISH probe (Figure 1a) and a significant correlation was seen between this hybridization and the general bacterial probe based on the scoring system $(p=0.02)$.
In 4 specimens Clostridium species were detected by using a mixed Clostridium spp. probe targeting C. perfringens, C. difficile, C. butyricum and C. paraputrificum. Two of those specimens were by histological examinations observed to exhibit pneumatosis intestinalis and a significant correlation $(\mathrm{p}<0.05)$ was found with the presence of the Clostridium spp even though the sample numbers are very small. In these two specimens $C$. butyricum and C. parputrificum were detected in high densities (Figure 1c), C. perfringens was detected in one of the specimens (figure 1d) whereas $C$. difficile was not detected in any of the slides. Nevertheless, no correlation was found between diagnosed neonates with pneumatosis intestinalis by $\mathrm{x}$-rays and the specimens colonised with Clostridium spp. Finally, there was no correlation between the presence of bacteria by FISH and NEC score, type of nutrition, antibiotic usage, or death.

\section{Characterisation of bacterial composition in tissues removed surgically from neonates with NEC}

Eight neonates were selected for further characterisation of the bacteria located in the lumen and mucus layer of the inflamed tissues. Four of these neonates had received antibiotics for less than two days while the other four neonates had received antibiotics more than 10 days. A $16 \mathrm{~S}$ rRNA gene library from each specimen was constructed. The individual tags $(\mathrm{N}=364)$ were assigned to the closest mono-Phylogenetic group in order to obtain a Phylogenetic classification. In total, 41 consensus tags were identified (Table 4). The frequencies of $16 \mathrm{~S}$ rRNA gene sequences from all specimens were grouped according to their overall phylogeny and the phyla were Proteobacteria (49.0\%), Firmicutes (30.4\%), Actinobacteria (17.1\%) and Bacteroidetes (3.6\%) (Figure 2). $\delta$-proteobacteria was the major detected class of the phylum Proteobacteria. The Shannon diversity index was calculated based on the total library cloning sequences for each neonate (Figure 3). The Shannon diversity index revealed two distinct groups. The neonates p3, p6, p17 and p24 clustered together with a low Shannon diversity index and were dominated by more than $50 \%$ of one genera of either Escherichia spp. or Enterococcus spp. In neonate p8, p20, p22 and p27, multiple bacterial genera were present with no single genus contributing with more than $30 \%$ of total bacteria (Figure 3 ). The differences in diversity could not be explained or correlated to clinical characteristics like NEC score, number of days with antibiotics, time of surgery, or gestational age.

The bacteria associated with the tissue in the individually neonates have the potential to reveal bacterial pathogens related to the pathogenesis of NEC. In the $\delta$ proteobacteria group Escherichia/Shigella genera 
Table 3 Fluorescent in situ hybridization (FISH) scores on intestinal specimens from 24 NEC patients

\begin{tabular}{|c|c|c|c|c|c|c|c|c|c|}
\hline $\begin{array}{l}\text { Patient } \\
\text { number }\end{array}$ & Tissue & $\begin{array}{c}\text { Days of } \\
\text { antibiotic }^{5}\end{array}$ & $\begin{array}{c}\text { NEC } \\
\text { score }\end{array}$ & EUB338 & Enterobateria & Clostridium $^{1}$ & Actinobactere & Lactobacillus & Bifidobateria \\
\hline 25 & $\begin{array}{c}\text { small } \\
\text { intestinal }\end{array}$ & 3 & 14 & 0 & 0 & 0 & 0 & 0 & 0 \\
\hline $26^{4}$ & $\begin{array}{c}\text { small } \\
\text { intestinal }\end{array}$ & 4 & 13 & 0 & 0 & 0 & 0 & 0 & 0 \\
\hline $9^{4}$ & $\begin{array}{c}\text { small } \\
\text { intestinal }\end{array}$ & 1 & 10 & 1 & 1 & 0 & 0 & 0 & 1 \\
\hline 2 & $\begin{array}{c}\text { small } \\
\text { intestinal }\end{array}$ & 1 & 15 & 1 & 0 & 0 & 2 & 0 & 0 \\
\hline 6 & $\begin{array}{c}\text { small } \\
\text { intestinal }\end{array}$ & 17 & 11 & 1 & 2 & 0 & 0 & 2 & 0 \\
\hline 8 & $\begin{array}{c}\text { small } \\
\text { intestinal }\end{array}$ & 1 & 12 & 1 & 0 & 0 & 0 & 0 & 0 \\
\hline 12 & $\begin{array}{c}\text { large } \\
\text { intestinal }\end{array}$ & 5 & 17 & 1 & 0 & 0 & 2 & 0 & 0 \\
\hline 14 & $\begin{array}{c}\text { small } \\
\text { intestinal }\end{array}$ & 15 & 13 & 1 & 1 & 1 & 1 & 2 & 0 \\
\hline 15 & $\begin{array}{c}\text { small } \\
\text { intestinal }\end{array}$ & 5 & 19 & 1 & 0 & 0 & 2 & 0 & 0 \\
\hline $16^{4}$ & $\begin{array}{c}\text { small } \\
\text { intestinal }\end{array}$ & 4 & 6 & 1 & 1 & 1 & 1 & 0 & 0 \\
\hline 27 & $\begin{array}{c}\text { small } \\
\text { intestinal }\end{array}$ & 4 & 8 & 1 & 1 & 0 & 0 & 0 & 0 \\
\hline 1 & $\begin{array}{c}\text { small } \\
\text { intestinal }\end{array}$ & 6 & 5 & 2 & 2 & 0 & 1 & 2 & 0 \\
\hline $3^{3}$ & $\begin{array}{c}\text { large } \\
\text { intestinal }\end{array}$ & 1 & 11 & 2 & 2 & 2 & 2 & 0 & 2 \\
\hline 7 & $\begin{array}{c}\text { small } \\
\text { intestinal }\end{array}$ & 5 & 13 & 2 & 2 & 0 & 1 & 0 & 0 \\
\hline $10^{4}$ & $\begin{array}{c}\text { small } \\
\text { intestinal }\end{array}$ & 4 & 13 & 2 & 1 & 0 & 0 & 2 & 0 \\
\hline $11^{4}$ & $\begin{array}{c}\text { small } \\
\text { intestinal }\end{array}$ & 7 & 7 & 2 & 1 & 0 & 0 & 2 & 0 \\
\hline 17 & $\begin{array}{c}\text { small } \\
\text { intestinal }\end{array}$ & 11 & 15 & 2 & 2 & 0 & 0 & 1 & 0 \\
\hline $18^{3}$ & $\begin{array}{c}\text { small } \\
\text { intestinal }\end{array}$ & 12 & 15 & 2 & 2 & 1 & 1 & 0 & 1 \\
\hline 19 & $\begin{array}{c}\text { small } \\
\text { intestinal }\end{array}$ & 4 & 19 & 2 & 2 & 0 & 1 & 1 & 0 \\
\hline 20 & $\begin{array}{c}\text { small } \\
\text { intestinal }\end{array}$ & 11 & 13 & 2 & 1 & 0 & 1 & 2 & 0 \\
\hline 21 & $\begin{array}{c}\text { small }^{2} \\
\text { intestinal }^{2}\end{array}$ & 2 & 12 & 2 & 2 & 0 & 1 & 0 & 0 \\
\hline $22^{4}$ & $\begin{array}{c}\text { small } \\
\text { intestinal }\end{array}$ & 1 & 13 & 2 & 2 & 0 & 1 & 0 & 0 \\
\hline 23 & $\begin{array}{c}\text { small } \\
\text { intestinal }\end{array}$ & 4 & 15 & 2 & 2 & 0 & 0 & 0 & 0 \\
\hline $24^{4}$ & $\begin{array}{c}\text { large } \\
\text { intestinal }\end{array}$ & 2 & 13 & 2 & 2 & 0 & 1 & 0 & 0 \\
\hline
\end{tabular}

The score was: 0: few bacteria;1: moderate number of bacteria; 2 : high number of bacteria.

${ }^{1}$ The Clostridium probe is a mixture of four specific probes targeting Clostridium species: C. perfringens, C. difficile, C. butyricum and C. parputrificum

${ }^{2}$ The neonates had tissues from both the small intestine and large intestine removed but FISH analysis was only done on the small intestinal tissues

${ }^{3}$ Pneumatosis intestinalis verified by histopathology

${ }^{4}$ Dead after the surgical operation

${ }^{5}$ Before NEC diagnose 

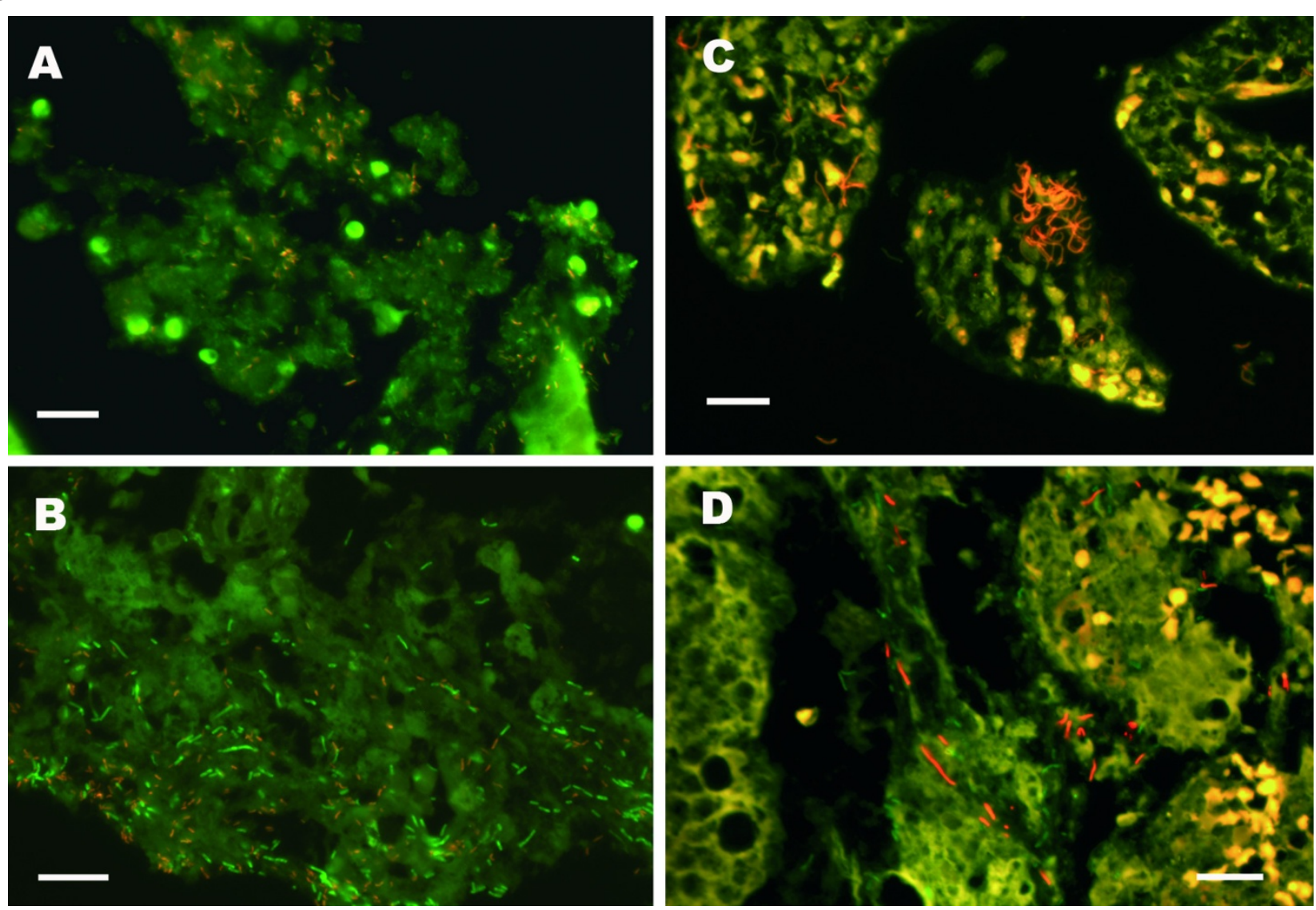

Figure 1 Epifluorescence micrographs of fluorescent in situ hybridized tissue samples taken from neonates diagnosed with necrotizing enterocolitis. All the specimens were hybridized with a general bacterial probe (EUB338) tagged with fluorescein (green colour) and group specific probes tagged with Cy3 (red colour). A) Visualization of Enterobacteria (GAM42a). B) Visualization of Actinobacteria ( pB00182). C) Visualization of Clostridium butyricum ( S-S-C. butyricum-663) in the two neonates where pneumatosis intestinalis was verified by histopathology. D) Visualization of Clostridium perfringens (S-S-C.perfring-185-a-A-18) in neonate number 3 with pneumatosis intestinalis.The scale bar is $20 \mu \mathrm{m}$ in all the micrographs.

dominated with a frequency of $45 \%$ out of all $\delta$-proteobacteria and were present in 5 of the 8 neonates with an average frequency of $24 \%( \pm 36 \%)$. The Enterobacteriaceae group consisted of virtually one tag but it was similar to genera of Citrobacter, Enterobacter (Klebsiella) and Erwinia and was detected in 4 of the neonates. The taxonomic class Clostridia contained 10 different tags belonging to a variety of different genera (Table 4), the two most prominent being Clostridium and Anaerococcus detected in four and three neonates, respectively. A tag matching the potential pathogen Finegoldia was found twice in two different neonates. One of the specimen characterised histologically exhibiting pneumatosis intestinalis was also observed to include the genus Clostridium. The most prevalent tag belonged to Ralstonia being present in 7 out of 8 neonates, with an average of $9 \%( \pm 5 \%) . R$. detusculanense, $R$. pickettii and $R$. insidiosa were revealed with more than $99 \%$ similarity (Figure 4).

\section{Discussion}

The establishment of the microbiota early in life and the symbiosis with the human gastrointestinal tract has important consequences for human health and physiology. The interactions can have beneficial nutritional, immunological, and developmental effect or even pathogenic effects for the host [13-16]. In this study the bacterial composition has been characterised for the first time directly on tissue samples from neonates with fulminate NEC. The specimens were collected from a single neonatal hospital unit with a consistent treatment and a similar environment over a period of 6 years. Even though, the study is naturally limited in number of patients this is the first description done in situ and not on surrogates in the form of faecal samples or experimental animals. FISH combined with laser capture microdissection ensured that only bacterial DNA from lumen and mucus was sampled and that no contaminations from the surrounding material or environment 
Table 4 The consensus tags from the 16S rRNA gene library

\begin{tabular}{|c|c|c|c|}
\hline Genus/family & class & typestrain & Sequence \\
\hline Corynebacterium & Actinobacteria & $10-27$ & CTTAACGCAGCAAGTCGAACGGAAAGGCCCAAGCTTGCTTGGGTACTCGAGT \\
\hline Acidimicrobium & Actinobacteria & $7-54$ & CTTAACGCAGCAAGTCGGCAAGCGGGTGCGTAACACG \\
\hline Actinomycetales & Actinobacteria & $\mathrm{C} 50$ & AACGATGAAGCCCAGCTTGCTGGGTGGATTAGTGGCGAAC \\
\hline Bifidobacterium & Actinobacteria & $\mathrm{C} 35$ & AACGGGATCCCAGGAGCTTGCTCCTGGGTGAGAGTGGCGAAC \\
\hline Clavibacter & Actinobacteria & $9-66$ & AATGCATGCAAGTCGAACGGTGATGTCAGAGCTTGCTCTGGCGGATCAGTGGCGAAC \\
\hline Corynebacterineae & Actinobacteria & B33 & AACGGAAAGGCCCTGCTTGCAGGGTGCTCGAGTGGCGAAC \\
\hline Micrococcineae & Actinobacteria & B54 & AACGATGAAGCCCAGCTTGCTGGGCGGATTAGTGGCGAAC \\
\hline Propionibacterium & Actinobacteria & $9-22$ & AACGGAAAGGCCCTGCTTTTGTGGGGTGCTCGAGTGGCGAAC \\
\hline Bradyrhizobium & $\alpha$-proteobacteria & $7-95$ & GCAAGTCGAGCGGGCATAGCAATATGTCAGCGGCAGAC \\
\hline Caulobacter & $\alpha$-proteobacteria & $5-10$ & AACGGATCCTTCGGGATTAGTGGCGGACGGGTGCGTAACACGTGG \\
\hline Rhodobacteriaceae & $\alpha$-proteobacteria & $9-24$ & AGCGAGGACTTCGGTTCTAGCGGCGGACGGGTGCGTAACACGTGAA \\
\hline Sphingomonadaceae & $\alpha$-proteobacteria & A48 & CCTAACGCAGCAAGTCGAACGAACTCTTCGGAGTTAGTGGCGGAC \\
\hline Bacillales & Bacilli & $10-49$ & AATGCATGCAAGTCGAGCGGAGTTGACGAGAAGCTTGCTTCTCGGATGCTTAGCGGCGGA \\
\hline Enterococcus & Bacilli & A45 & AACGCTTCTTTTTCCACCGGAGCTTGCTCCACCGGAAAAGAGGAG \\
\hline Exiguobacterium & Bacilli & $9-61$ & AGCGCAGGAAGCCGTCTGAACCCTTCGGGGGGACGACGGTGGAATGA \\
\hline Lactobacillus & Bacilli & $6-3$ & CCTAATGCATGCAAGTCGAGCGAGCGGAACCAACAGATTTACTTCGGTAATGACGTT \\
\hline Staphylococcus & Bacilli & B55 & AGCGAACAGACAAGGAGCTTGCTCCTTTGACGTTAGCGGCGGAC \\
\hline Bacteroidales & $\begin{array}{l}\text { Bacteroidetes/Chlorobi } \\
\text { group }\end{array}$ & $5-73$ & СTTAATACATGCAAGTCGAGGGGCAGCATGGTCTTAGCTTGCTAAGGCTGATGGCGACCG \\
\hline Porphyromonas & $\begin{array}{l}\text { Bacteroidetes/Chlorobi } \\
\text { group }\end{array}$ & $7-33$ & CTTAACACATGCAAGTCGAGGGGCAGCATTATTTTAGCTTGCTAAGATAGAT \\
\hline Prevotella & $\begin{array}{l}\text { Bacteroidetes/Chlorobi } \\
\text { group }\end{array}$ & $7-66$ & TCCTAACGCATGCAAGTCGAGGGGCAGCATGGAAGAAGCTTGCTTCTTCTGATGGCGA \\
\hline Burkholderiales & $\beta$-proteobacteria & $9-31$ & AACGGTAACAGGTCTTCGGACGCTGACGAGTGGCGA \\
\hline Cupriavidus & $\beta$-proteobacteria & A70 & AACGGCAGCGCGGGCTTCGGCCTGGCGGCGAGTGGCGA \\
\hline Ralstonia & $\beta$-proteobacteria & $5-36$ & AACGGCAGCATGATCTAGCTTGCTAGATTGATGGCGAGTGGCGA \\
\hline zoogloea & $\beta$-proteobacteria & $10-86$ & AACGGTAACAGGGAGCTTGCTCCGCTGACGAGTGGCGA \\
\hline Anaerococcus & Clostridia & $6-29$ & AACGATGAAACTTAATTGATTTCTTCGGAATGATTTTAAGTGGATTAGTGGCGG \\
\hline Clostridium & Clostridia & $\mathrm{C} 1$ & AGCGATGAAGCTCCTTCGGGAGTGGATTAGCGGCGGAC \\
\hline Dialister & Clostridia & A7 & AACGGGAAGAGATGAAGAGCTTGCTCTTTATCGAATCCAGTGGCAAAC \\
\hline Faecalibacterium & Clostridia & $\mathrm{C} 42$ & AACGGAGTTGAGAGGAGCTTGCTTTTCTTGACTTAG \\
\hline Finegoldia & Clostridia & $10-63$ & AACGGGATTTAGTAGACAGAAACCTCGGTGGAAGATTACTAATGAGAGTGGCGAACGGGT \\
\hline Lachnospiraceae & Clostridia & A96 & AACGAAGCGATTAAGAGGAAGTTTTCGGATGGAATCTTAATTGACTGA \\
\hline Papillibacter & Clostridia & C16 & AACGGAGCACCTTGAAAGAGACTTCGGTCAATGGATGAGACTGCTT \\
\hline Peptoniphilus & Clostridia & $7-94$ & AGCGATGAAATTTTGACAGATCCCTTCGGGGTGAAGATAAAATGGATTAGCGGCGGA \\
\hline Ruminococcaceae & Clostridia & $9-81$ & AACGGAGTTAATTTTGTTGAAGTTTTCGGATGGATACGAAGTTAACTTAGTGGCGA \\
\hline Veillonella & Clostridia & $9-73$ & AACGGACAGATAGAGAGCTTGCTCTCTTGAAGTTAGTGGCGAAC \\
\hline Cystobacteraceae & $\Delta$-proteobacteria & $7-10$ & AACGCAGCAAGTCGGGTGCGTAACACGTGGG \\
\hline Acinetobacter & $\gamma$-proteobacteria & $9-10$ & AACGCAGCAAGTCGAGCGGAGATGAGGTGCTTGCACCTTATCTTAGCGGCGGAC \\
\hline Enhydrobacter & $\gamma$-proteobacteria & A49 & AACGATGATTATCTAGCTTGCTAGATATGATT \\
\hline Enterobacteriaceae & $\gamma$-proteobacteria & $\mathrm{C} 5$ & AACGGTAGCACAGAGAGCTTGCTCTCGGGTGACGAGTGGCGGAC \\
\hline Pseudomonas & $\gamma$-proteobacteria & C19 & AGCGGTAGAGAGAAGCTTGCTTCTCTTGAGAGCGGCGGAC \\
\hline Rickettsiella & $\gamma$-proteobacteria & A22 & CCTAACGCAGCAAGTCGAACGGCAGCACAGTAAAGATTTCGGTCTTTAT \\
\hline Shigella/Escherichia & $\gamma$-proteobacteria & $\mathrm{C} 26$ & AACGGTAACAGGAAACAGCTTGCTGATTTGCTGACGAGTGGCGGAC \\
\hline
\end{tabular}

The individual tags $(\mathrm{N}=364)$ were assigned to the closest mono-phylogenetic group. 


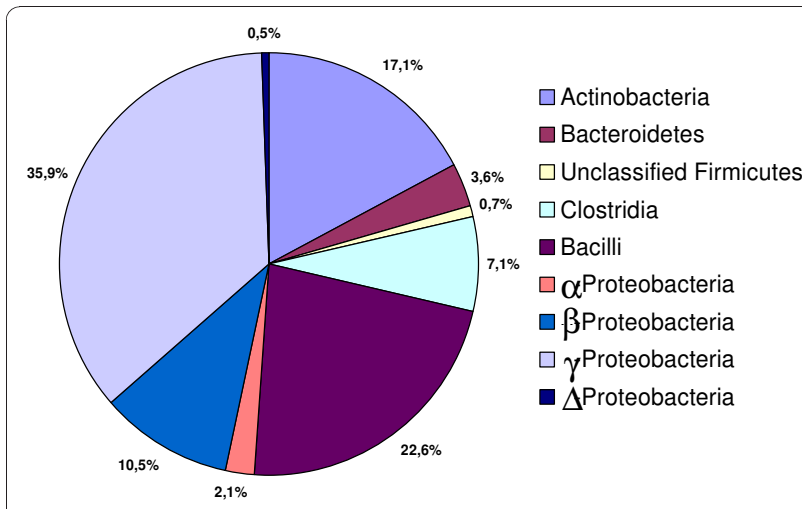

Figure 2 The total bacterial composition from eight intestinal tissue samples by $16 \mathrm{~S}$ rRNA gene clone library. The $\gamma$ -

Proteobacteria dominated the total bacterial composition whereas the class Clostridia only accounted for a total of $7.1 \%$

could occur. Furthermore, cloning and pyrosequencing used here has previously been shown to be efficient for the characterization of the intestinal microbiota [17-19]. The presence of bacterial colonization in the small intestine and large intestine was documented and visualized by a general bacterial FISH probe and this method has previously been used to reveal bacterial spatial distribution in the intestine of experimentally colonised animals $[20,21]$. In general, tissues with disease were heavily colonised by bacteria but we could not correlate the bacterial colonisation to NEC-score, days with

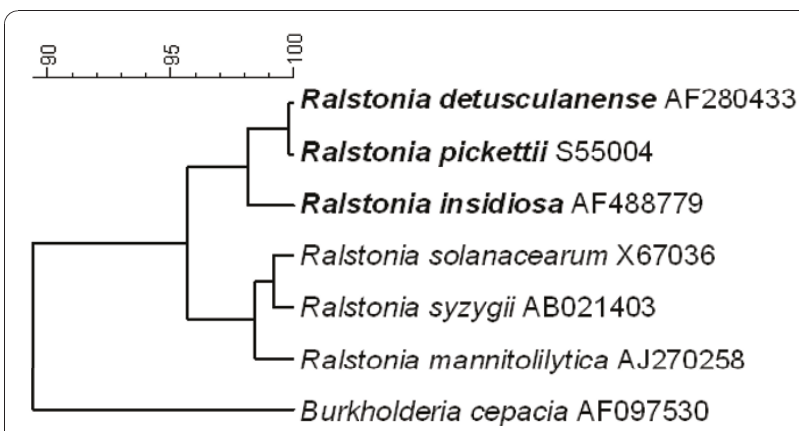

Figure 4 Phylogenetic relationship among Ralstonia detected in the tissue samples from the NEC infants. $R$. detusculanense, $R$. pickettii and $R$. insidiosa did all have more than $99 \%$ similarity with the matched Ralstonia tag from the 16S rRNA gene clone library from this study. The bacteria names and the accession numbers are shown. antibiotics or type of antibiotics nor type of nutrition. This colonization might be because of resistance to or wrong choice of antibiotics or because the antibiotics do not reaches the bacteria because of stop of blood supply. It has recently been shown that antibiotics do not clear gut microbiota in neonates but reduce the diversity of bacterial species [22]. We were therefore interested in finding which bacterial groups that colonized the surgical removed tissues.

The dominance of Proteobacteria could explain the susceptibility of preterm neonates to NEC or as a course

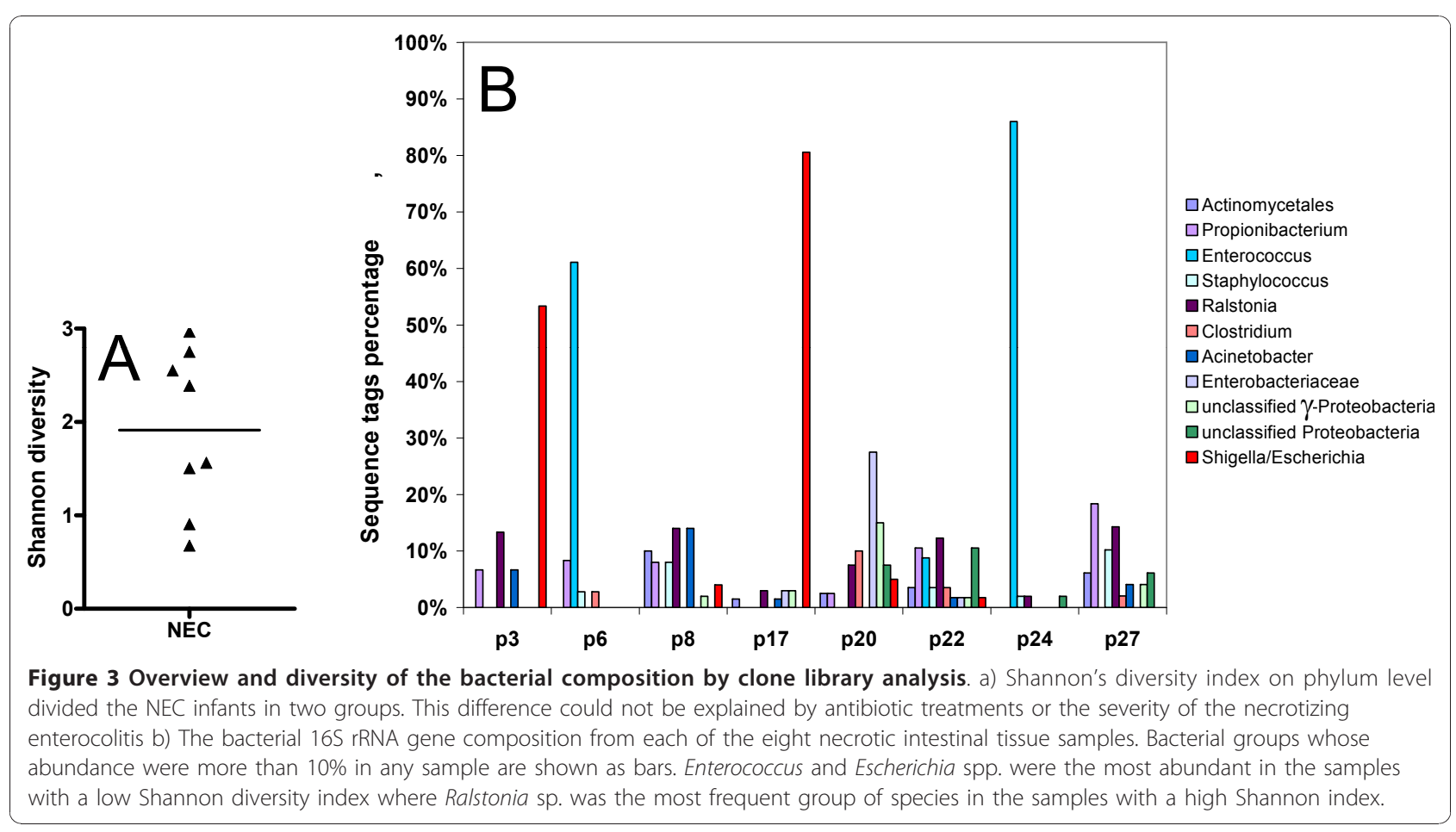


of the antibiotic treatments that all neonates received in this study. From the 16S rRNA gene library the $\delta$-proteobacteria was dominated by Escherichia-like organisms and to a lesser extent with Enterobacteria. It has previously been described by Wang et al. [18] that $\delta$-proteobacteria dominated the bacterial composition in faecal samples from neonates with NEC but they also found a lower Shannon diversity for NEC patients compared to the control group [18]. This could have been due to the antibiotic treatments. In this study there was no difference in the bacterial composition or Shannon diversity index after long term antibiotic administration ( $>10$ days) compared to less than two days of antibiotic treatments. Furthermore, no difference in bacterial composition was found regardless of the type of antibiotics used for treatment, in contrast to the antibiotic selection seen by Gewolb et al. [23]. In general, a very high variation was observed in the bacterial composition of the specimens as well as different diversity indexes and if it had been possible to analyse more samples it would perhaps had been possible to correlate the different variables with the colonization. The colonization of the preterm intestine could have been speculated to be very homogeneous since the neonates were at the same hospital unit (environment) even though Palmer et al., [17] showed that the composition and temporal patterns of the microbial communities in stool samples from term babies varied widely from baby to baby for their first year of life. However the composition of the intestinal microbiota in healthy pre- or term neonates present in the small intestine is not yet known due to the lack of samples $[17,18,24,25]$.

Previous studies based on culture techniques have focused on single organisms as predisposing for NEC $[7,26,27]$. Clostridium spp. and especially C. perfringens due to the fermentation of carbonhydrate substrates to hydrogen gas has been suspected $[3,6,9]$. Very few neonates were colonised with Clostridium spp. in this study but there was a significant correlation between a positive signal from the probes for Clostridium spp and pneumatosis intestinalis as verified by histopathology. It was specified that this Clostridium colonization was due to C. butyricum and C. parputrificum. A previous study has shown that these two lactose fermenting clostridium species can induce cecal NEC-like lesions in a gnotobiotic quail model and these lesions may be linked to short-chain fatty acid production [28]. There was no correlation with pneumatosis intestinalis found by X-ray and Clostridium spp. and maybe pneumatosis intestinalis described on X-ray is different from the pneumatosis intestinalis described on tissue surgically removed. It seems therefore like C. butyricum and C. parputrificum are responsible for pneumatosis intestinalis when verified by histopathology, but because of the low frequency of Clostridium spp in our samples we believe that the pneumatosis intestinalis is a secondary effect of NEC and that these Clostridia are not the primary pathogens of NEC.

Ralstonia and Propionibacteria were detected in most of the specimens where laser capture microdissection was used. Ralstonia spp. is a new genus including former members of Burkholderia spp. (Burkholderia picketti and Burkholderia solanacearum). Burkholderia spp. has been described in children suffering of NEC [29] and Ralstonia picketti has been reported to be a persistent Gram-negative nosocomial infectious organism [30]. R. picketti can cause harmful infections and is mainly considered as an opportunistic pathogen of little clinical significance but $R$. pickettii isolates have been reported to be resistant or had decreased susceptibility to aminopenicillins, ureidopenicillins, restricted-spectrum cephalosporins, ceftazidime, and aztreonam [31]. The major conditions associated with $R$. picketti infection are bacteraemia/septicaemia and respiratory infections/pneumonia. The bacteria has been isolated from patients diagnosed with Crohn's disease and cystic fibrosis from multiple sides including sputum, blood, wound infections, urine, ear swabs and nose swabs, and cerebrospinal fluid $[30,32,33]$. Diversity in an ecosystem is important in establishing and preventing dominance by a single pathogenic species. In the samples with Ralstonia spp. there were a relatively high diversity of different bacteria and if Ralstonia had had a primary effect we would expect a higher dominance of Ralstonia and a lower bacterial diversity. Therefore, we cannot conclude from this study whether Ralstonia has any effects, on the development of NEC and further studies have to elucidate this or/and if Ralstonia sp. was present because of a higher resistance to the antibiotic treatment.

Propionibacterium spp. have previously been described in faecal specimens $[17,34]$. The presence of this genus has been reported to be the second largest on the adult body and predominant in sebaceous sites [35]; it has probably been found in neonates' small intestine because of skin contact between the mother and the neonate. The reason why it has not been found in higher densities in many other gastrointestinal studies of the microbiota is a general underestimation of Actinobacteria created by the choice of primers and a dilution effect in faeces [17].

\section{Conclusion}

This study emphasized the possibility to examine the microbial composition directly on excised human tissues to avoid biases from faecal samples or culturing. Although a large variability of bacteria was found in most of the analyzed specimens, no single or combination of known potential pathogenic bacterial species was 
dominating the samples suggestive NEC as non-infectious syndrome. However there was a general high presence of Proteobacteria and Ralstonia sp. which may be due to the antibiotic treatment that all neonates received in this study and a significant correlation between the finding of C. butyricum \&C. paraputrificum and the few histological pneumatosis intestinalis found in this study.

\section{Methods}

\section{Patient characteristics and sample collection}

The study was done retrospectively on neonates with NEC hospitalised from January 2001 to December 2005. All neonates were hospitalised at a single level III Neonatal Intensive Care Unit (NICU) at Rigshospitalet, Copenhagen, Denmark. All neonates had surgical intervention and samples of removed tissue were formalinfixed and paraffin-embedded at the Department of Pathology, Rigshospitalet. The study was subjected to ethical review and approved by the Ethical Committee for Copenhagen and Frederiksberg, Denmark (KF 01 268923). Patient's records were reviewed in order to characterise the clinical findings, disease progression and clinical outcome. The data gathered from each infant were: gestational age, weight at birth, onset of symptoms, feeding prior to onset of NEC, antibiotic usage prior to operation of NEC, and outcome.

\section{NEC disease evaluation (NEC-score)}

Unfortunately, there is no standard pathological characterization of NEC. We decided to characterize the tissue macroscopic from the characterization made by the pathology that originally looked at the tissue and histologically after haematoxylin and eosin (HE) staining. All histologically samples were independently evaluated by two trained pathologists; at the Department of Pathology, Rigshospitalet and at The National Veterinary Institute, Technical University of Denmark.

\section{Macroscopic evaluation}

Perforation was noted not scored, hemorrhagic mucosa $+/$ - necrotic areas, score 5, pneumatosis intestinal score 5. Amount of tissue $<10 \mathrm{~cm}$ score $1,10-30 \mathrm{~cm}$ score 2 , $>30 \mathrm{~cm}$ score 3 .

\section{Histology evaluation}

The formalin-fixed and paraffin-embedded samples were sectioned $3 \mu \mathrm{m}$, mounted on slides and stained with HE. The HE slides were graded as follows: (A) Necroses volving; a) luminal epithelia, b) whole mucosa, c) submucosa, d) tunica muscularis; (B) Vascularity; a) oedema, b) bleeding, c) micro-thrombing, d) haemosiderine, (C) Inflammation; a) unspecific (granulocytes), b) eosinophils, c) vasculitis, d) pseudomembranes, e) granulation tissue, f) granulomas, g) granulomas, h) fibrosis, i) atrophy 1)mucosa 2) all other layers; e) and f) was not included in the score but used to graduate the tissue in acute or chronic NEC. (D) Various, 1) ganglion cells 2) non-ganglion cells. All histopathological characteristics were scored one except (D) that was used to distinguish NEC from Hirschsprung's disease. The NEC-score score is the addition of the macroscopic evaluation and the histology evaluation

\section{Bacterial detection by $16 \mathrm{~S}$ rRNA in situ Hybridization on Formalin-Fixed Tissue Sections}

Paraffin was removed of the tissue sections with xylene and dehydrated in $96 \%$ ethanol for $30 \mathrm{~min}$. All specimens were hybridized with both a general bacterial probe EUB338 and with selective probes. Probes were synthesized at Eurofins MWG Operon (Ebersberg, Germany) and described in Table 1 . Two probes (S-S-C. paraputri-181 and S-S-C. butyricum-663) were designed in ARB http://www.arb-silva.de in this study. The probes were approved for their specificity to closest bacterial type strains by an in silico probe search in RDP release $10 \mathrm{http} / / / \mathrm{rdp} . \mathrm{cme}$.msu.edu/, and experimental verified for signal intensities and specificity by FISH targeting pure culture of C. butyricum CCUG4217 ${ }^{\mathrm{T}}$; C. paraputrificum CCUG32755 ${ }^{\mathrm{T}}$; C. difficile ATTC17857 and C. perfringens NCTC8449 injected into a piece of pig lung treated as the rest of the tissue samples.

Hybridization was done in $20 \mu \mathrm{l}$ of hybridization buffer $(100 \mathrm{nM}$ Tris, $\mathrm{pH}$ 7.2. $0.9 \mathrm{M} \mathrm{NaCl}, 0.1 \%$ sodium dodecyl sulphate) added $100 \mathrm{ng}$ of probe at $45^{\circ} \mathrm{C}$ for 16 $\mathrm{h}$ in a humidified chamber. Slides were washed in 100 $\mathrm{ml}$ of preheated $\left(37^{\circ} \mathrm{C}\right)$ hybridization buffer for $15 \mathrm{~min}$ and subsequently in $10 \mathrm{ml}$ of preheated $\left(37^{\circ} \mathrm{C}\right)$ washing solution (100 mM Tris, pH 7.2, $0.9 \mathrm{M} \mathrm{NaCl})$ for $15 \mathrm{~min}$. Slides were rinsed in water and air-dried. All slides were scored as follows: 0) no or low density of bacteria, 1) moderate density of bacteria, 2) high density of bacteria.

\section{NEC tissues used for Laser Capture Micro dissection}

Eight intestinal tissue samples were included. The microdissection was performed on tissues excised from 4 neonates that were treated with antibiotics less than 2 days and from 4 neonates treated with antibiotics 10 days or more before surgery. Three $\mu \mathrm{m}$ sections of the tissues were cut (knife was changed between cuts) and mounted on the $0.17-\mathrm{mm}^{\text {PALM }}{ }^{\circledR}$ POL-membrane slides (P.A.L.M. Microlaser Technologies AG, Bernried, Germany) and kept at $4^{\circ} \mathrm{C}$ until use. The slides were hybridized with bacterial probes as previously described.

\section{Laser Capture Microdissection}

A PALM Robot-Microbeam system (P.A.L.M. Microlaser Technologies AG) consisting of an Axivert $200 \mathrm{M}$ microscope (Carl Zeiss, Oberkochen, Germany) equipped for fluorescence with a 100-W Hg lamp, a 40x/1.30 oil Fluar objective (Carl Zeiss), filter set XF53 
(Omega Optical, Brattleboro, VT, USA) and the PALM RoboSoftware version 1.2 (P.A.L.M Microlaser Technologies AG) was used. Bacteria were visualized by FISH using the general bacterial probe EUB338 and dissected from both the intestinal lumen and mucus of the surgical tissue by the cutting and catapulting function, RoboLPC as previous described [12]. The micro-dissected area from the lumen and mucus associated tissues were never in contact with any external contaminators because the micro-dissected area is cut by a laser and "transported" to the tube by a photonic force and against gravity as described by Carl Zeiss AG, Deutschland http://www.zeiss.de/. The risk for external contaminators is therefore minimal.

The catapulting material was collected in the cap of a $200 \mu \mathrm{l}$ Thermo-Tube (ABgene, Epsom, UK) containing $20 \mu \mathrm{l}$ proteinase $\mathrm{K}$ buffer. The microdissected material was digested in proteinase $\mathrm{K}$ buffer $(10 \mathrm{mM}$ Tris- $\mathrm{HCl}$, $\mathrm{pH}$ 8.0, $150 \mathrm{mM} \mathrm{NaCl}, 10 \mathrm{mM}$ EDTA, $0.1 \%$ sodium dodecyl sulphate, $1 \mathrm{U}$ proteinase $\mathrm{K}$ ) at $55^{\circ} \mathrm{C}$ for $72 \mathrm{~h}$. Subsequently, the proteinase $\mathrm{K}$ was inactivated at $95^{\circ} \mathrm{C}$ for $15 \mathrm{~min}$. Two $\mu \mathrm{l}$ of solution were subsequently used as template for the polymerase chain reaction (PCR).

\section{Clone library and sequencing of intestinal bacteria}

The primers Bact64f and Bact109r1 (Eurofins MWG Operon ) were used for $16 \mathrm{~S}$ rRNA gene amplification of the hyper variable region V1 from the small subunit ribosomal RNA gene (Table 1). PCRs (always including a non template control) were done in $20 \mu \mathrm{l}$ volumes containing $1 \times$ PCR buffer $[20 \mathrm{mM}$ Tris- $\mathrm{HCl}(\mathrm{pH} 8.4)$ and $50 \mathrm{mM}$ $\mathrm{KCl}$ ], $200 \mu \mathrm{M} \mathrm{dNTP}, 500 \mathrm{nM}$ each primer, $3.3 \mathrm{mM} \mathrm{MgCl}$, and $1 \mathrm{U}$ of Pfu DNA polymerase (Invitrogen Corporation, Carlsbad, CA), which creates blunt end fragments. The thermal profiles were as follows: an initial denaturation step at $94^{\circ} \mathrm{C}$ for $3 \mathrm{~min} ; 30$ cycles of $94^{\circ} \mathrm{C}$ for $30 \mathrm{~s}, 50^{\circ} \mathrm{C}$ for $30 \mathrm{~s}$, and $72^{\circ} \mathrm{C}$ for $30 \mathrm{~s}$; and a final elongation step at $72^{\circ} \mathrm{C}$ for $5 \mathrm{~min}$. The amplicons were purified by using phenol/ chloroform $(\mathrm{P} / \mathrm{C}, \mathrm{pH} 8.0)$, and the DNA was precipitated with $2.5 \mathrm{M}$ ammonium acetate in ethanol. After two washes with $80 \%(\mathrm{v} / \mathrm{v})$ ethanol, the DNA pellet was dried and resuspended in $10 \mu \mathrm{l}, 0.2 \mu \mathrm{l}$ filtrated, double-distilled water. Following the manufacturer's descriptions the cloning was done by using a Zero blunt TOPO cloning kit (Invitrogen Corporation). Fifty to hundred colonies from each cloning were picked and sequenced by pyrosequencing. A PYROMark Q96 ID was used to short DNA sequencing of the approximately 40-60 bp clone insert using the recommended protocol (Biotage AB, Uppsala, Sweden) as described previously using the primer PyroBact64f [19]. The sequences (tags) were imported into the software BioNumerics 4.61 and manually checked, aligned and filtered for high quality sequences. Sanger sequencing with an Applied Biosystem 3130 Genetic Analyzer (Foster
City, CA, USA) was used to check consensus tags for the pyrosequencing accuracy. The Sequence match analysis tool in the Ribosomal database project $10 \mathrm{http}: / / \mathrm{rdp} . \mathrm{cme}$. msu.edu/ was used to assign the Phylogenetic position of each consensus tag. The search criteria were for both type and non-type strains, both environmental (uncultured) sequences and isolates, near-full-length sequences $(>1200$ bases) of good quality. If there was a consensus at the genus level the tag was assigned this taxonomic classification. If no such consensus was found, the classification proceeded up one level to family and again if no taxonomic affiliation could be assigned the tag continued to be proceeded up the tree as described by Huse et al., [36]. In some cases it was not possible to assign a domain and these sequences might represent new novel organisms or the sequences might be biased, in these cases the tags were excluded from the dataset. In total 364 sequences were finally included in the alignment.

The phylogenetic analysis was done by downloading $16 \mathrm{~S}$ rRNA gene sequences longer than 1,200 base pair from the RDP database of the Ralstonia type strains http://rdp.cme.msu.edu. The RDP alignment was used and a phylogenetic tree was constructed by using the Ward algorithm in the software Bionumerics. Burkholderia cepacia (GenBank accession no. AF097530) was used as an out-group.

\section{Statistics}

The statistical analysis was done in two steps: First, the association between one predictor at a time and the NEC score was analysed by robust least squares methodology adjusting for gestational age. This is equivalent to a normal linear GEE modal with working independence correlation structure on child level. For each predictor the estimated change in expected NEC score is reported with Wald 95\% confidence limits in parentheses. The overall association between the predictor and the NEC score is evaluated by a robust score-test.

Second, we formulate a normal linear GEE model including gestational age and all predictors with a robust score-test p-value below 0.1 in the above analyse. This multivariable model is then reduced by backwards elimination using 0.05 as a cut-off level.

All analyses were performed using PROC GENMOD in SAS version 9.1 (SAS Institute, Cary, NC).

\section{Acknowledgements}

We wish to thank the technical staffs at National Veterinary Institute for assistance with the FISH and technical staff Annie Ravn Pedersen at National Veterinary Institute for the histological work. We want to attribute our late colleague S. Bodé, MD DSc.

\section{Author details}

${ }^{1}$ Statens Serum Institut, Artillerivej 5, 2300 Kbh. S, Denmark. ${ }^{2}$ National Veterinary Institut- DTU, Bülowsvej 27, 1790 Copenhagen V, Denmark. 
${ }^{3}$ Neonatel Department 5023, Rigshospitalet, Blegdamsvej, 2100 Kbh. $\varnothing$, Denmark. ${ }^{4}$ Pathologic Institut, Rigshospitalet, Blegdamsvej, 2100 Kbh. $\varnothing$, Denmark. ${ }^{5}$ Faculty of Life Sciences, University of Copenhagen, Bülowsvej 17 1870 Frb., Denmark.

\section{Authors' contributions}

BS carried out the data mining from the hospital studies, carried out the in situ studies and participated writing the manuscript. SB; MB and KAK participated in the design of the study and coordination and helped to draft the manuscript. PLP and TKJ performed the histopathology of the samples and scored the degree of NEC in each tissue sample. CP did the statistical analysis. JK participated in collecting the samples. LM carried out the sequencing and sequence analysis and participated in writing the manuscript. All authors read and approved the final manuscript.

Received: 8 October 2010 Accepted: 12 April 2011

Published: 12 April 2011

\section{References}

1. Lin PW, Stoll BJ: Necrotising enterocolitis. Lancet 2006 368(9543):1271-1283

2. Blakely ML, Lally KP, McDonald S, Brown RL, Barnhart DC, Ricketts RR, et al: Postoperative outcomes of extremely low birth-weight infants with necrotizing enterocolitis or isolated intestinal perforation: a prospective cohort study by the NICHD Neonatal Research Network. Ann Surg 2005, 241(6):984-989.

3. Lee JS, Polin RA: Treatment and prevention of necrotizing enterocolitis. Semin Neonatol 2003, 8(6):449-459.

4. Albanese CT, Rowe MI: Necrotizing Enterocolitis. Semin Pediatr Surg 1995, 4(4):200-206.

5. Claud EC, Walker WA: Hypothesis: inappropriate colonization of the premature intestine can cause neonatal necrotizing enterocolitis. FASEB 2001, 15(8):1398-1403.

6. Alfa MJ, Robson D, Davi M, Bernard K, Van Caeseele P, Harding GK: An outbreak of necrotizing enterocolitis associated with a novel Clostridium species in a neonatal intensive care unit. Clin Infect Dis 2002, 35(Suppl 1):101-105.

7. Bell MJ, Shackelford P, Feigin RD, Ternberg UL, Brotherton T: Epidemiologic and bacteriologic evaluation of neonatal necrotizing enterocolitis. $J$ Pediatr Surg 1979, 14(1):1-4.

8. Carbonaro CA, Clark DA, Elseviers DA: Bacterial pathogenicity determinant associated with necrotizing enterocolitis. Microb Pathog 1988, 5(6):427-436

9. Dittmar E, Beyer P, Fischer D, Schafer V, Schoepe H, Bauer K, Schlosser R: Necrotizing enterocolitis of the neonate with clostridium perfringens: diagnosis, clinical course, and role of alpha toxin. Eur J Pediatr 2007, 20:10

10. Suau A: Molecular tools to investigate intestinal bacterial communities. $J$ Pediatr Gastroenterol Nutr 2003, 37(3):222-224.

11. Zoetendal EG, von Wright A, Vilpponen-Salmela T, Ben Amor K, Akkermans AD, De Vos WM: Mucosa-associated bacteria in the human gastrointestinal tract are uniformly distributed along the colon and differ from the community recovered from feces. Appl Environ Microbiol 2002, 68(7):3401-3407.

12. Klitgaard K, Molbak L, Jensen TK, Lindboe CF, Boye M: Laser capture microdissection of bacterial cells targeted by fluorescence in situ hybridization. Biotechniques 2005, 39(6):864-868.

13. Backhed F, Ley RE, Sonnenburg JL, Peterson DA, Gordon Jl: Host-bacterial mutualism in the human intestine. Science 2005, 307(5717):1915-1920.

14. MacDonald TT, Gordon JN: Bacterial regulation of intestinal immune responses. Gastroenterol Clin North Am 2005, 34(3):401.

15. Penders J, Thijs C, Vink C, Stelma FF, Snijders B, Kummeling I, van den Brandt PA, Stobberingh EE: Factors influencing the composition of the intestinal microbiota in early infancy. Pediatrics 2006, 2118(2):511-521.

16. Xu J, Gordon Jl: Inaugural article: honor the symbionts. Proc Natl Acad Sci 2003, 100(18):10452-10459.

17. Palmer C, Bik EM, Digiulio DB, Relman DA, Brown PO: Development of the human infant intestinal microbiota. PLOS Biol 2007, 5(7):e177.

18. Wang Y, Hoenig JD, Malin KJ, Qamar S, Petrof EO, Sun J, et al: $16 \mathrm{~S}$ rRNA gene-based analysis of fecal microbiota from preterm infants with and without necrotizing enterocolitis. ISME 2009, 3(8):944-954.
19. Luna RA, Fasciano LR, Jones SC, Boyanton BL, Ton TT, Versalovic J: DNA pyrosequencing-based bacterial pathogen identification in a pediatric hospital Setting. J Clin Microbiol 2007, 45(9):2985-2992.

20. Favre-Bonte S, Licht TR, Forestier C, Krogfelt KA: Klebsiella pneumoniae capsule expression is necessary for colonization of large intestines of streptomycin-treated mice. Infect Immun 1999, 67(11):6152-6156.

21. Sangild PT, Siggers RH, Schmidt M, Elnif J, Bjornvad CR, Thymann T, et al: Diet- and colonization-dependent intestinal dysfunction predisposes to necrotizing enterocolitis in preterm pigs. Gastroenterology 2006, 130(6):1776-1792.

22. Tanaka S, Kobayashi T, Songjinda P, Tateyama A, Tsubouchi M, Kiyohara C, et al: Influence of antibiotic exposure in the early postnatal period on the development of intestinal microbiota. FEMS Immunol Med Microbiol 2009, 56(1):80-87.

23. Gewolb IH, Schwalbe RS, Taciak VL, Harrison TS, Panigrahi P: Stool microflora in extremely low birthweight infants. Arch Dis Child Fetal Neonatal Ed 1999, 80(3):167-173.

24. Gronlund MM, Lehtonen OP, Eerola E, Kero P: Fecal microflora in healthy infants born by different methods of delivery: permanent changes in intestinal flora after cesarean delivery. J Pediatr Gastroenterol Nutr 1999, 28(1):19-25.

25. Harmsen HJM, Wildeboer-Veloo AC, Raangs GC, Wagendorp AA, Klijn N, Bindels JG, Welling GW: Analysis of intestinal flora development in breast-fed and formula-fed infants by using molecular identification and detection methods. J Pediatr Gastroenterol Nutr 2000, 30(1):61-67.

26. Bell MJ, Shackelford PG, Feigin RD, Ternberg $J L$, Brotherton T: Alterations in gastrointestinal microflora during antimicrobial therapy for necrotizing enterocolitis. Pediatrics 1979, 63(3):425-428.

27. Millar MR, Mackay P, Levene M, Langdale V, Martin C: Enterobacteriaceae and neonatal necrotising enterocolitis. Arch Dis Child 1992, 67:53-56.

28. Waligora-Dupriet A, Dugay A, Auzeil N, Huerre M, Butel M: Evidence for Clostridial Implication in Necrotizing Enterolitis through Bacterial Fermentation in a Gnotobiotic Quail Model. Pediatr Res 2005, 58(4):629-635.

29. Deris ZZ, Van Rostenberghe H, Habsah H, Noraida R, Tan GC, Chan YY, et al: First isolation of Burkholderia tropica from a neonatal patient successfully treated with imipenem. Int I InfectDis 2009, 22:5.

30. Ryan MP, Pembroke JT, Adley CC: Ralstonia pickettii: a persistent Gramnegative nosocomial infectious organism. J Hosp Infect 2006, 62(3):278-284.

31. Nordmann P, Poirel L, Kubina M, Casetta A, Naas T: Biochemical-genetic characterization and distribution of OXA-22, a chromosomal and inducible class $D$-lactamase from Ralstonia (Pseudomonas) pickettii. Antimicro. Agents and Chem 2000, 44(8):2201-2204.

32. Burns JL, Emerson J, Stapp JR, Yim DL, Krzewinski J, Louden L, Ramsey BW, Clausen CR: Microbiology of sputum from patients at cystic fibrosis centers in the United States. Clin Infect Dis 1998, 27(1):158-163.

33. Riley PS, Weaver RE: Recognition of Pseudomonas pickettii in the clinical laboratory: biochemical characterization of 62 strains. J Clin Microbiol 1975, 1(1):61-64

34. Eckburg PB, Bik EM, Bernstein CN, Purdom E, Dethlefsen L, Sargent M, Gill SR, Nelson KE, Relman DA: Diversity of the human intestinal microbial flora. Science 2005, 308(5728):1635-1638.

35. Grice EA, Kong HH, Conlan S, Deming CB, Davis J, Young AC, et al: Topographical and temporal diversity of the human skin microbiome. Science 2009, 324(5931):1190-1192.

36. Huse SM, Dethlefsen L, Huber JA, Mark Welch D, Relman DA, Sogin ML: Exploring microbial diversity and taxonomy using SSU rRNA hypervariable tag sequencing. PLoS Genet 2008, 4(11):e1000255.

37. Alm EW, Oerther DB, Larsen N, Stahl DA, Raskin L: The Oligonucleotide Probe Database. Appl Environ Microbiol 1996, 62(10):3557-3559.

38. Manz W, Amann R, Ludwig W, Vancanneyt M, Schleifer KH: Application of a suite of $16 \mathrm{~S}$ rRNA-specific oligonucleotide probes designed to investigate bacteria of the phylum Cytophaga-Flavobacter-Bacteroides in the natural environment. Microb 1996, 142:1097-106.

39. Roller C, Wagner M, Amann R, Ludwig W, Schleifer KH: In situ probing of Gram-positive bacteria with high DNA G+C content using 23 S rRNAtargeted oligonucleotides. Microbiol 1994, 140:2849-2858.

40. Harmsen HJM, Elfferich P, Schut F, Welling GW: A 16S rRNA-targeted probe for detection of Lactobacilli and Enterococci in faecal samples by fluorescent in situ hybridization. Microb Ecol Health Dis 1999, 11:3-12. 
41. Langendijk PS, Schut F, Jansen GJ, Raangs GC, Kamphuis GR, Wilkinson MH, Welling GW: Quantitative fluorescence in situ hybridization of Bifidobacterium spp. with genus-specific $16 \mathrm{~S}$ rRNA-targeted probes and its application in fecal samples. Appl Environ Microbiol 1995, 61:3069-3075.

42. Yu ZT, Yu M, Morrison M: Improved serial analysis of V1 ribosomal sequence tags (SARST-V1) provides sa rapid, comprehensive, sequencebased characterization of bacterial diversity and community. Environ Microbiol 2006, 8(4):603-611.

doi:10.1186/1471-2180-11-73

Cite this article as: Smith et al:: Community analysis of bacteria

colonizing intestinal tissue of neonates with necrotizing enterocolitis.

BMC Microbiology 2011 11:73.

Submit your next manuscript to BioMed Central and take full advantage of:

- Convenient online submission

- Thorough peer review

- No space constraints or color figure charges

- Immediate publication on acceptance

- Inclusion in PubMed, CAS, Scopus and Google Scholar

- Research which is freely available for redistribution

Submit your manuscript at www.biomedcentral.com/submit
C Biomed Central 